\title{
ОСОБЛИВОСТІ ВЖИВАННЯ ПЕЙОРАТИВА «НЕГІДНИК» В УКРАЇНСЬКІЙ МОВІ
}

У статті шляхом аналізу дефініиій пейоратива «негідник» подано опис поняттєвих ознак, визначено граматичні особливості, досліджено функціонування та транспозицію изього слова в сучасній українській мові. Розкрито його семантику як лінгвокультурного поняття, а також визначено особливості мовного вираження, підкреслено, шьо лексемі «негідник» притаманні неабиякі дистрибутивні можливості. Доведено, шуо граматична трансформація аналізованого слова вплинула не тільки на втрату первинного значення, а й на його сполучуваність з іншими словами.

Ключові слова: пейоратив, лексема, транспозиція, семантика, лексико-семантичні особливості, внутрішня форма слова.

The article is devoted the analysis of functioning of pejorative "scoundrel» in modern Ukrainian, to opening of its semantics as a linguocultural concept, to determination of features of linguistic expression.

There is a sufficient number of research works devoted to the study of lexical-grammatical features of individual tokens in linguistics. But today the question of the functioning and transposition of pejorative «scoundrel» has not been fully studied in the modern Ukrainian language.

In the article, by means of the analysis of the definitions of lexeme "scoundrel» in the Academic Dictionary of the Ukrainian Language, the Etymological Dictionary, and Dictionary of Synonyms, a description of the conceptual features of this lexeme is given, grammatical features are determined, and its transposition phenomena are analyzed in the system of the Ukrainian language.

The token of a scoundrel denotes a despicable, vile, dishonorable person. These definitions do not have a specific or unique focus on the characteristics of a person who is called a scoundrel. Typically, this word can be used in all situations where a speaker intends to verbally express a negative attitude towards anyone, that is, has a general investment meaning: his semantics does not indicate what the villain did, but emphasizes that his actions lower than any moral standards.

The grammatical transformation of the analyzed word has affected not only at the loss of its original meaning, but also its compatibility with other words.

Prospects of the research are the study of verbal representation of the lexeme scoundrel in a separate fiction text.

Key words: pejoratives, lexeme, transposition, semantics, lexical and grammatical features, internal form of the word.
Постановка проблеми. Однією 3 найважливіших проблем сучасної лінгвістики є дослідження комунікативної взаємодії індивідів. Увага мовознавців зосереджена на вивченні того, як людина використовує мову у спілкуванні та як у мовних одиницях відображається сама людина. Кожен народ має свої моральні норми й ідеали, які дозволяють його громадянам оцінювати один одного та свої дії, а також орієнтуватися в довколишньому середовищі, а реалізуються вони лише через слово.

У сучасній українській мові для називання людей і звертання до них використовують власні імена. Однак особа, до якої необхідно звернутися, не завжди знайома мовцеві, а іноді він і не хоче називати іiі на ім'я - йому це неприємно, бо особистісні якості або поведінка цієї людини не відповідають моральним та соціальним нормам і правилам суспільства. У зв'язку 3 цим використовується загальний іменник - слово, яке позначає ставлення мовця до людини, зокрема його негативну оцінку, несхвалення, осуд, іронію чи презирство. Наприклад, сьогодні зневажливу лексику зазвичай можна почути, коли характеризують політиків, депутатів, чиновників: бандюки, бидло, кліки, покидьки, наволоч, сволота, шваль. Ці та подібні слова у мовознавстві називають пейоративами - «...лексичними одиницями, в структуру значення яких входить конотативний аспект (негативна емотивна сема), за допомогою якого виражається негативне ставлення мовця до адресата» [2, с. 3$]$.

Пейоративність пронизує всі аспекти людського життя й пов'язана 3 категорією емотивності, яка надає спілкуванню життєвості, природності, емоційності [7].

Актуальність представленого дослідження визначається загальним інтересом до пейоративної лексики, а також необхідністю вивчення іiї лексико-семантичних та функційних особливостей.

Аналіз наукових досліджень і публікацій. На рубежі XX - XXI століть в українському мовознавстві значно посилився інтерес до слова як мовно-функціональної одиниці, проблем визначення та реалізації у мовленні лексико-семантичного та стилістичного потенціалу слів різних тематичних груп (серед них і пейоративи), оскільки саме словесному матеріалу належить провідна роль у ситуаціях спілкування.

Лінгвісти досліджують пейоративну лексику в різних напрямах, як-от:

- пейоративна й інвективна лексика в міжособистісному конфлікті (Л. А. Білоконенко); 
- пейоративи в епістолярному автопортретуванні Тараса Шевченка (С. К. Богдан);

- конкретні етнічні пейоративи (А. І. Грищенко, Н. А. Николина, О. С. Коробкова, О. С. Архипова, Н. Г. Степанова);

- пейоративні найменування чоловіків у середньоверхньонімецькій мові (О. А. Карасенко);

- пейоративи за ознакою соціальної безпеки

(B. I. Карасик);

- структурно-семантичні особливості пейоративів (А. В. Ковалевська);

- пейоративи як засіб вербалізації вираження негативного емоційного стану, критерії та методи визначення пейоративної лексики (О.В.Кульчицька);

- формальне та лексико-семантичне засоботворення іменників зі значенням пейоративності (О. В. Мошак) та ін.

Таким чином, незважаючи на те, що пейоративна лексика досліджена значною кількістю лінгвістів, однак залишається ще достатньо невирішених моментів, які стосуються даної проблематики, а отже, потребують подальшої розробки.

Мета статті - проаналізувати лексико-семантичні та функційні особливості вживання пейоратива «негідник» в українській мові.

Виклад основного матеріалу. Особливе місце серед пейоративів посідає лексема «негідник», що позначає підлу, нікчемну, мерзенну, безчесну людину [10, Т. 5, с. 277]. Цікаво, що вказані означення не мають конкретної або єдиної орієнтації на ознаки людини, яку називають негідником. Як правило, ця лексема може вживатися в усіх ситуаціях, коли мовець має намір словесно виразити негативне ставлення до будь-кого, тобто має загальне інвективне значення: семантика не вказує на те, що саме зробив негідник, але акцентує увагу на тому, що його дії нижчі за всякі моральні норми.

Запозичений із польської мови іменник негідник $€$ похідним від твірного багатозначного прикметника негідний, але не всі лексичні значення твірного реалізуються у похідному $[5 ; 6]$. Лексичне значення твірного негідний ширше від значення слова негідник. Використовуючи 11-томний Словник української мови [10], проаналізуємо значення лексеми негідний: 1. Якого не можна використовувати; непридатний. 2. Який не заслуговує на повагу, наслідування, не вартий кого-, чого-небудь; недостойний. 3. Підлий, нікчемний, мерзенний, безчесний (про людину та іiі поведінку) [10, Т. 5, С. 277].

У зв'язку з цим, похідний іменник негідник мотивований прикметником негідний тільки у третьому значенні: той, хто здійснює ганебні, підлі вчинки; безчесна, підла людина.

Існує легенда про походження лексеми «негідник». Нагадаємо їі.

На Русі був звичай щзодо покарання злочинщчв: на лютому морозі винуватия прив'язували до стовпа $i$ повільно обливали холодною водою, поки він не перетворювався в крижану статую. Ката, який приводив вирок у виконання, тобто підливав воду, називали негідником, а замерзлий у результаті таких дій зловмисник відповідно іменувався мерзотником (бо замерзав) [6].

У сучасній українській мові перше та друге значення твірного прикметника негідний не отримало свого подальшого розвитку в похідному негідник. Але так було не завжди.

Спочатку лексема негідник не мала негативного значення. Негідниками називали міське або сільське населення, яке було зобов'язане платити податки, наприклад, купців, дрібних ремісників та ін., тобто людей незнатного роду, простолюдинів, усіх тих, хто не належав до дворянської або боярської знаті [6].

На перше значення прикметника негідний (якого не можна використовувати; непридатний), що характерне для іменника негідник, указував радянський лінгвіст Сергій Наровчатов, зазначаючи, що слово «негідник» стало вживаним приблизно двісті п'ятдесят років тому. Зокрема, так називали молодих хлопців і чоловіків, які не підлягали призову в армію (Не служив в армї - значить негідник! - не годен, тобто не придатний) [8]. Пізніше ця лексема стала вживатися у ширшому значенні: негідником називали особу, яка загалом була непридатна до чого-небудь. У статті «Про антисемитизм» Максим Горький писав: «Негодяй - не ругательство. Негодяй - точное определение человека, не годного для жизни (Горький 1931, c. 82). Саме така семантика слова «негідник» відображена і в пісні М. Борзикіна, засновника і учасника рок-гурту «Телевізор»: У мене на лобі «7б»/- не придатний до військової служби,/ Не придатний до нормальної сім 'ï, / Простий в любові і дружбі. Негідник!

До середини ХІХ століття значення слова «негідник» вже набуває легкого образливого забарвлення i реалізується другим значенням твірного прикметника негідний (який не заслуговує на повагу, наслідування, не вартий кого-, чого-небудь; недостойний). У середовищі ліберальної інтелігенції цей термін застосовується до людей, які стоять на нижчому щаблі соціальної драбини. Після Жовтневої революції, коли поділ на бідних і багатих втратив актуальність, термін «негідник» стає образою і набуває значення «не придатний бути справжньою людиною», означаючи особу безпринципного, безсовісного, здатного на підлість зрадника [8].

Отже, відбулася мовленнєва трансформація: 3 часом семантика слова «негідник» змінилася і набула тільки негативного значення.

Семантичне поле лексеми «негідник» досить широке і представлене семами, що відрізняються відтінками значень та стилістичним вживанням: мерзотник, поганеиь - підсил. розм., паразит - підсил. розм.; підлотник, личина, гадюка, гад, гадина, змія, змій, зміюка - підсил. лайл. і зневажл. (про злу, підступну людину); капосник розм., пакосник (пакісник) - розм. (той, хто робить негідні, безчесні вчинки); падло, падлюка, париивець, паскуда, паскудник, плюгавець, собака, пес, стерво, супостат - заст., иибенник - заст. (ужив. як лайливе слово); свиня - лайл., свинюка (свиняка) - підсил. лайл. (про непорядну, нечемну, невдячну людину); нехрист, бусурман, босяк (ужив. лайливо щодо людини, поведінка й учинки якої сприймаються негативно, несхвально, -3 метою образити іiі, показати свою зневагу до неї) [9].

Для підкреслення негативно-оцінного ставлення мовця до особи / осіб часто вживають поряд із лексемою «негідник» декілька контекстуальних синонімів, коли наступний синонім підсилює значення попереднього. Цю функцію якнайкраще підкреслює зміст речень: 
1. Iз двома пейоративами, з'єднаними сурядним зв'язком (Ось иі негідники та поганці, які влаштували полювання за нами, сядуть на свої місия в зону, і так надовго, років на 1-15! (О. Ремезовська). А я кажу, щуо всі вони - негідники й брехуни! -лементувала огрядна жінка, стискаючи в обох руках великі сумки (С. Небайдужий). Я таки егоїстка, якщо так довго люблю одного і того самого негідника й падлюку (M. Матіос).

У цих прикладах автори прагнуть віднайти найоптимальніший варіант для реалізації виражальних можливостей слова і пейоративами «негідники та поганціџ, "негідники й брехуни", «негідник й падлюка» називають негативних осіб, які викликають несхвалення, осуд через учинки, що суперечать моралі, звичаям, традиціям соціуму. Як правило, такі пари лексем уживаються, коли мовець має намір словесно оформити своє негативне ставлення до когось із метою образи, оцінки діалогічного партнера, його приниження. Але так буває не завжди. Наприклад, у реченнях Журналісти втягуються в пошуки праведників і негідників (О. Пасховер). Серед тих, кому залишилися лічені хвилини герої й праведни$\kappa и$, чесні люди й негідники, сміливі та байдужі (B. Портников) спостерігаємо протиріччя - протиставляються дві лексеми, констатуючи відсутність гідності у негідника і наявність справедливості, правильності, чесності, благородності у праведника.

2. Із трьома пейоративами, серед яких лексема «негідник» може бути як на першому місці, так i в середині або ж у кінці. Усі три члени найчастіше пов'язані безсполучниковим зв'язком, іноді другий та третій компоненти об'єднуються за допомогою сурядних сполучників. Наприклад: Прикладом антиукраӥнської пропаганди служить фільм «Матч смерти». Якщио там людина говорить украӥнською мовою, то це зрадник, негідник, колаборант (І. Щупак). ... порушуються права людини..., ... коли журналіст оголошує підсудного негідником, покидьком, сволотою (П. Александров). У фіналі ией викінчений негідник, злодій і гвалтівник гине від руки Василя Хмарного... (I. Кочерга). Негідник, злодій, єретик! / За кучму сю твою велику / Як дам лящза тобі я в пику... (I. Котляревський). Я оголосив війну негідникам, мерзотникам i злодіям (О. Романчук). Там, де турботливі мама $i$ тато разом із свойм прізвищем намагаються передати в спадщину і своє щңастя, виростають підлотники, негідники, ледарі...(В. Сухомлинський). Принципом ї̈ жстття стає девіз дикуна, негідника і хулігана (В. Сухомлинський).У нас так: якщо ти держслужбовець, то все - ти злодій, негідник, корупціонер (Iз газ.). Артемій Троїцький закликав голосувати на всіх майбутніх виборах «за Росію без жллбів, боягузів $\boldsymbol{i}$ негідників» (О. Караулова).

3. Із чотирма пейоративами: ...як звичайні люди стають розмінними пішаками в іграх сильних світу цього. Київ, Росія, Свропа; олігархи, авторитети, негідники та праведники; любов, смерть, зрада, інтриги... (С. Ухачевський). Якщчо ви почитаєте американську пресу, ви дізнаєтеся щзо і Республіканська, і Демократична партії США - ие збіговиська закінчених бариг, корупціонерів, злочинців $\boldsymbol{i}$ негідників (Д. Вовнянко). Емочї викликають лайливі слова й вульгаризми негідник, шкуродер, шахрай, ... (Н.Кльова).Щобсиновітакогокрутія РадоновіКроулі, тому негідникові, гравцеві, шахраєві $\boldsymbol{i}$ вбивці, Матільда віддала більшу частину свого багатства?

4. Досить рідко у текстах трапляються п'ять контекстуальних синонімів, об'єднаних негативним змістом. Наприклад: Цілі ичикли віршів Маяковський присвятив бюрократам, кар'єристам, хабарникам, підлабузникам, негідникам. Я жити хочу, жити! Хай ким завгодно - негідником, бандитом, гадом повзучим, черв'яком, тарганом, але тільки жити!» (I. Чонкін).

Властивою ознакою більшості контекстуальних пейоративів $\epsilon$ стилістична маркованість. Наприклад, лексеми поганиі, падлюки, покидьки, сволота, мерзотники, гадина подані в академічному словнику української мови як лайливі, розмовні; nidлабузник, ублюдок - презирливі. Поряд із ними як нейтральні трапляються слова негідник, бюрократ, кар'єрист, корупціонер, олігарх, злодій. Але усі вони у своєму лексичному значенні мають негативне емоційне та експресивне забарвлення.

Поряд із назвою особи чоловічого роду (негідник) вживається назва для позначення жіночого роду негідниця (Покинь тую негідницю, Возьми й мене робітницю (А. Метлинський). 3 одного боку, у цих назв спільні значення (корелятивні іменники називають особу за однією і тією ж ознакою), а з іншого - у них $\epsilon$ семантичні відмінності (співвідносні іменники називають осіб різної статі).

Існує і числове співвідношення слів негідник, негідниия - негідники, негідниці: Живуть у світі три негідники: Щевстигайло, Забувайло $і$ Відкладайло (Угорське присл). Саме на одному з таких сайтів негідниі й копіювали фото реальних дітей (Із газ.).

Пейоративу негідник притаманні надзвичайно великі дистрибутивні можливості:

1. Прикметник + іменник, де залежний прикметник узгоджується з іменником негідник та називає його різні ознаки:

А) Вік людини: А якийсь малий негідник деякий час навіть переслідував й мене. "Ти -маленький негідник. Малолітні негідники напали на бездомних, які їх не чіпали (Із газ.). Це молодий, дуже амбітний негідник (Із газ.). Ми шоковані тим, щзо по всьому світу мільйони дітей стають жертвами злочинів та егоїзму дорослих негідників (Із газ.). Ясна річ, старий негідник обдурює нас, як це він завжди робить... (П. Загребельний).

Іноді часто вживане означення малий у словосполученні малий негідник підсилюється іншим означенням і отримує додаткову смислову сему негативності. Наприклад: Ти, нікчемний малий негіднику! Паскудний малий негідник! Циннобер є й буде, ... малим потворним негідником... (Е. Гофман).

Б) Належність до нації, держави, народу, території, партії: Нині ми маємо національних негідників... (газета «Голос України). «Дл чого їй (Украӥні), цікаво, була Незалежність? Щоб потрапити у нову залежність, вже не лише від чужих падлюк, а й від своїх власних украӥнських негідників?»-риторично запитує протагоніст ... (Л. Костенко). Сили нації висмоктуються купкою промосковських негідників, які дограбовують Україну $і$ не дають їй розвиватися (І. Федик). Кримських негідників покроково вводили в уже наявний план ... Нацистські негідники не шкодували нікого (І. Дедей). 
В) Розмір: Я більший негідник, ніж ти (В. Вовк). Найбільщий негідник! Гайдамака. Постій! Невинную кров ллєш (І. Котляревський); ...Яиенюк, Гриценко чи Тігіпко, фанатично прагнучи влади, від того у карлейлівському сенсі не стають меншими негідниками, бо паразитують на тимчасових наслідках недовершених революиійних змін (Із газ.). Артуре! Еріксон - великий негідник, ие правда. Але правда й те, щуо він урятував тобі життя (О. Авраменко). «Це м'ясник, ие негідник, розумієте? Найвищого ступеня негідник (М. Кипоть). То був страшенний негідник, пане! (Г. Сенкевич).

Г) Час : Про наших сучасних негідників ...сказано стільки епітетів, щзо й додати нема чого. Якби не путлер, все було б по-іншому, сьогоднішні негідники при владі можуть тільки йому завдячувати, а народ опинився в пастиі (Із газ.). Після Польщчі вірити в московські ідеали може тільки останній дурень $i$ останній негідник (В. Стус).

Г) Зовнішні ознаки: Бачите ви цьього огрядного негідника?(ІІ газ.). Микита навіть, заходячи до кабіни, ... висловив надію, що вони обов'язково знайдуть лисого негідника (В. Врублевський). Степан - не безпринципний і спритний негідник, як Жорж Дюруа, ш⿻ змінював жінок з кар'єрних міркувань $i$ жив за рахунок коханок (В. Підмогильний).

Д) Внутрішні (психологічні) риси: Хитрий негідник! Дізнався про номер нашого будинку (Із газ.). Глупий негідник набагато краще розумного негідника (О. Гарань). На початку твору він постає брутальним негідником (К. Степанець). Так, я егоїстичний негідник (С. Гаврилюк). Ось він, той дурний $i$ безсоромний негідник, щчо втік від мене (Джек Лондон). У світі повно пройдисвітів або зухвалих негідників... (Ф. Саватер). Тому нам не завадить мати напохваті такого безпринципного негідника ... (О. Авраменко). Будь-яку революцію задумують романтики, втілюють в життя фанатики, а ї̈ плодами користуються відверті негідники (Т. Карпейль). ... «великі» втрачають землю під ногами і перетворюються на самозакоханих негідників (В. Ружинський).

Е) Головний, відомий, надзвичайний у якомусь відношенні; рідкісний, винятковий: Головний негідник (підступний Чорномор) приймає образ Руслана, затягає Людмилу в свої тенета ... (В. Діброва). Художниия «оживила» відомих негідників. ... як справжній негідник, так і ідеальний святий обирає, за великим рахунком, те ж саме (Р. Гайнлайн). $\boldsymbol{A}$ ти унікальний негідник? (С. Заплетнюк). Постаті, щзо змальовувалися протягом століть як «ідеальний негідник» або «ідеальний герой», подано тут як живі й повнокровні, сповнені протиріч характери (С. Абрамович).

Для підсилення негативної семи, закладеної в слові негідник, у текстах художнього, публіцистичного та розмовного стилів зустрічається нанизування означень до цієї лексеми, кожне з яких також має негативне значення. Наприклад: Я зневажаю ФІФА, в цій організації -мерзосвітні, корупційні негідники (Д. Гордон в ефірі телеканалу News One). До того, щз наші політики - аморальні, хамовиті негідники, ми уже звикли... (О. Базар). Він крав речі людей, яких заарештовував $і$ вбивав, $і$ німиі, які дивилися на ие крізь пальиі, зневажали його як найманого, залежного, темного негідника $i$ злодія (О. Фадєєв).
Також означення можуть знаходитися після означуваного слова негідник. Наприклад: Негідник! Брудний, брехливий... У цьому випадку вони підсилюють, уточнюють лексему негідник.

Іноді поєднуються парадоксальні, контрастні й несумісні поняття (поєднання непоєднуваного). Одне з них - прикметник із позитивним значенням, а друге негідник (в основі - груба, зневажлива, негативна сема).

Таким чином, на думку О. В. Кульчицької, «пейоративна лексика уподібнюється хамелеону: вона здатна змінювати своє забарвлення та передавати різноманітні відтінки переживань та почуттів» [4, с. 242].

У результаті зіткнення суперечливих компонентів лексема негідник отримує додаткове значення 3 боку позитивного прикметника, протилежного їй за змістом. Хоча, якщо людина негідник, то про іiі гідність ми не можемо говорити, бо це не сумісно 3 нашим розумінням людини. У самій семантиці слів закладена неможливість їх одночасного вживання стосовно однієї особи. Наприклад, наше захоплення людьми виражається означеннями прекрасні, милі, романтичні, харизматичні, а негідник відповідно викликає негативні емоції, але поєднання таких слів є: книга Аберкромбі Джо має назву «Прекрасний негідник»; арабський поет Мутанаббі, звертаючись до негідників, називає їх милими (Скажу лиш: такий вже ией світ, негідники милі й подібні йому); Оксана Щур, аналізуючи оповідання В. Підмогольного «Третя революція», зазначає: "...Степан розумний, сильний, перспективний, він харизматичний негідник»; Олексій Іванович Швабрін у І. Мушина: ... По суті, суто романтичний негідник (як зауважує Мирський, це взагалі «єдиний у Пушкіна негідник»); В. Лозовий, голова Хмельницької обласної адміністрації, попереджає: «Шановні негідники, які хочуть якимось чином нажитися, використовуючи посади, то я вам не раджу иьього робити»; Сергій Бокін іронічно стверджує: "Який неймовірний негідник!».

Часто вказані поєднання слів підкреслюють складність характеру, внутрішню суперечність психічного стану людини, підсилення іронічного, зневажливого, презирливого ставлення до неї. Шекспірівський Гамлет звертається до свого дядька Клавдія: «Усміхнений негіднику проклятий!» (проклятий негідник - лайливе звертання, в якому прикметник усміхнений підкреслює почуття зневаги).

У текстах також трапляються досить несподівані означення до лексеми «негідник». Наприклад, пружинно-спіральний, екранний, мелодраматичний, запеклий, неприборканий: Майстрували нам стелю до млості, до одуру, із найкращих ідей, з настановами згідно, знявши мірку з пресованих бовдурів $i$ пружнино-спіральних негідників (Л. Костенко). ... на зйомках «Альошчиного кохання» Биков не міг дати (за сценарісм) ляпаса екранному негідникові (В. Войтенко). Справжній мелодраматичний негідник! Він єдиний, кого Кручинина пробачити не зможе ніколи (Г. Котов).

2. Іменник + іменник, де негідник $(u)$ - залежне слово (непрямий додаток у родовому відмінку). Наприклад: країна негідників, страх негідників, прихисток для негідників (Л. Костенко), мари проти негідників, ... руки негідників на горлі Революиії гідності (Із газ.). 
Відомий також вислів «закон негідників» - так називають закон проти усиновлення російських сиріт американськими родинами. Відома п'єса О. Островського «На всякого мудреця досить простоти» в польських театрах йшла під назвою «Записки негідника».

Трапляються іменникові словосполучення, в яких лексема негідник(u) - головне слово: негідники проти негідників.

Іноді трапляються двоназви (двонайменування) того самого предмета: певна загальна назва + лексема негідник (оцінно-якісна назва). Наприклад: Залишаючи суддів-негідників на посадах, влада допомагає формуванню негативного ставлення до судової системи. Він разом зі своӥми друзями-негідниками вигадали иңю війну в Іраціі. ... як висловився політик, убезпечити країну від президентів-негідників. ... обмінювала на наших героїв таких же злочинців-негідників. Це робили чиновники-негідники, $і$ ви хочете знати їхні імена ... Близько 9\% чоловіків-негідників 6 Україні вважають, щзо побиття жінки є... (Із газ.).

3. Словосполучення 3 діссловами. Аналіз сполучуваності $з$ дієсловами виявив три типи:

1) Зв'язок із діссловом, при якому іменник негідник виступає об'сктом дії: не голосуйте за негідника, не біитеся негідників, «... люблю одного і того самого негідника й падлюку» (М. Матіос), треба позбуватися негідників при владі... (Із газ.), ...набожна Ізабелла нарікає Клаудіо безсовісним негідником ... (В. Шекспір). Різних негідників я ненавиджу не менш, ніж ви! (В. Москалець). Цілі цикли віршів Маяковський присвятив бюрократам, кар'єристам, хабарникам, підлабузникам, негідникам.

2) Зв'язок із діссловами, при яких іменник неzідник є суб'єктом дії: Негідники обрали негідників! Нехай негідники займаються своєю благодійністю в іншому місиі. Той негідник загрожує всім нам. Якийсь негідник розбив ї̈ муровану підпору (Із газ.).

3) Зв'язка + іменник негідник в орудному або називному відмінках (у цьому випадку входить до складу складеного іменного присудка). Наприклад: Тут М. Штейна називали пройдохою $\boldsymbol{i}$ негідником (М. Шатров). Брехня, щзо він негідник! (Г. Красінський). Цей чоловік - страшний негідник. Хлопеиь виявився негідником. Був він баламутом, a тепер щее й негідником стане, - врадили діди (П. Супруненко).

4) Займенник + лексема негідник, причому займенники можуть бути різних розрядів, наприклад:

- вказівні: Через оцих негідників я маю на весь світ дивитися крізь темне скельие? (С. Журахович). Я постраждав від рук цих негідників. Нехай ті негідники займаються своєю благодійністю в іншому місиі. Той негідник загрожує всім нам. ...;

- означальні: За ними ганятимуться наркоторговиі, продажні полічейські й інші негідники ... Жоден негідник з місї̈ ООН.... Кожеен негідник $i$ мародер має дістати по заслузі... . 3'являється, як тінь батька Гамлета, щоб розправлятися з усілякими негідниками (В. Васильченко). Чи не виникає у вас іноді думки, щзо Бог повинен ивидше втрутитись у справи людей і відразу знищити всіх негідників?;

- неозначені: Якийсь негідник розбив ї̈ муровану підпору. ...не подавав, оскільки не хотів, щоб на мої гроші який-небудь негідник купив собі ... (А. Сенчук).
5) Числівник (кількісний або порядковий) + лексема негідник: Двоє негідників вбили украӥнського nатріота за украӥнську мову (О. Тягнибок). I багато негідників, які під них рядяться (Із газ.). «Хай Веррес злодій, хай святотатещь, хай перший негідник $i$ злочинець... (М. Цицерон).

6) Як реакція людини на різні обставини, події реальної дійсності використовується непохідний вигук негідник (негідники). Часто він поєднується 3 часткою або займенником. Наприклад: $\boldsymbol{A x}$, неzіdник росте! Ох же і негідник! - обурилась вона і по-

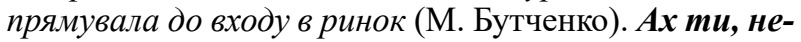
гідник! Та як ти зважився дурити шановних людей? (М. Старицький).

Дублювання лексем посилює значення жалю, досади, розчарування, наприклад: Негідник! $\boldsymbol{A x}$ негідник! (Плаче.) Степан Аркадійович (визирає з ванної, потім підбігає до Емми Андріївни, стривожено). Що сталося?! Сонечко, що сталося ... (В. Нестайко).

Лексема негідник (негідники) уживається як вигук (переважно при звертанні - лайливе слово): - Heгідники! - враз зарепетував він. - Мерзотники! - затупотів він ногами. - Обормоти! Хто дозволив ноги й руки мотузками перев'язувати? (Ю. Смолич).

Висновки. Аналіз мови художніх та публіцистичних текстів дав змогу з'ясувати, що відбулася зміна значення пейоратива негідник 3 нейтрального до негативного. Сучасна лексема негідник містить емотивну сему, за допомогою якої виражається негативне ставлення мовця до адресата, але не завжди: вживаючи даний пейоратив, мовець має на увазі принизливе та презирливе ставлення до нього. Однак у деяких випадках слово негідник використовується з позитивною або іронічною семантикою.

Таким чином, лексема негідник має широкі дистрибутивні можливості. Граматична трансформація аналізованого слова вплинула не тільки на втрату первинного значення, а й на його сполучуваність 3 іншими словами.

Подальші наші наукові розвідки плануємо спрямувати на дослідження порівняння лексико-семантичних та функційних особливостей лексеми негідник у близькоспоріднених мовах.

\section{СПИСОК ВИКОРИСТАНОЇ ЛІТЕРАТУРИ}

1. Білоконенко Л. А. Пейоративна й інвективна лексика в міжособистісному конфлікті. Філологічні студії. Науковий вісник Криворізького національного університету. 2012. № 7. Ч. 2. С. 119-127.

2. Голод О. Є. Особливості семантики та функціонування пейоративної лексики в сучасній німецькій мові : автореф. дис. ... канд. філол. наук : 10.02.04. Львів, 2001. 18 с.

3. Карасик В. И. Язык социального статуса. Москва : ИТДТК «Гнозис», 2002. 333 с.

4. Кульчицька О. В. Про деякі критерії та методи визначення пейоративної лексики. Вісник Житомирського державного університету. 2014. Вип. 4. С. 242245.URL:http://nbuv.gov.ua/UJRN/VZhDU 2014448 (дата звернення: 10.08.2020).

5. Походження лайок. URL: Frankivchany.if.ua. 9794-pokhodzenni-laiok (дата звернення: 05.09.2020). 
6. Походження, тлумачення і значення слова «негідник». URL: http://yrok.pp.ua/serednya-osvta/3258pohodzhennya-tlumachennya-znachennya-slovanegdnik.html (дата звернення: 07.08.2020).

7. Селиванова Е. А. Основы лингвистической теории текста и коммуникации : монографическое учебное пособие. Киев : Фитосоциоцентр, 2002. 336 с.

8. Словник (не)пристойних виразів. URL: Dobriporady.pp.ua/5683-Slovnik-nepristoynih-virazy (дата звернення: 12.08.2020).
9. Словник синонімів української мови : у 2 т. / упор. А. А. Бурячок, Г. М. Гнатюк, С. І. Головащук та ін. Київ : Наукова думка, 1999-2000.

10. Словник української мови : в 11 т. / за ред. І. К. Білодіда ; АН УРСР, Інститут мовознавства. Київ : Наукова думка, 1970-1980.

Дата надходження до редакиї: 31.10.2020 p. 